\title{
Comparison of Histological Characteristics of Dried and Fresh Amnion Membranes and Dura Mater in Non-Human Primate (Macaca fascicularis)
}

\author{
Astrina Rosaria Indah, ${ }^{1,2}$ Hendrikus Masang Ban Bolly, ${ }^{1,3,4}$ Ahmad Faried, ${ }^{4,5}$ Muhammad Zafrullah Arifin, \\ Achadiyani, ${ }^{5}$ Firman Fuad Wirakusumah ${ }^{5}$ \\ ${ }^{1}$ Faculty of Medicine Universitas Cenderawasih Jayapura, Papua, Indonesia, ${ }^{2}$ Graduate School of Biomedical \\ Sciences Master Program, Faculty of Medicine Universitas Padjadjaran Bandung, Indonesia, ${ }^{3}$ Doctoral Program \\ of Biomedical Sciences Master Program, Faculty of Medicine Universitas Padjadjaran Bandung, ${ }^{4}$ Department \\ of Neurosurgery Faculty of Medicine Universitas Padjadjaran/Dr. Hasan Sadikin General Hospital Bandung, \\ Indonesia, ${ }^{5}$ Stem Cell Working Group Faculty of Medicine Universitas Padjadjaran, Bandung, Indonesia
}

\begin{abstract}
Amniotic membrane (AM), a hospital waste product, is a potential source for tissue donor. There are several types of AM, namely dried and fresh-AM. AM being challange to be grafted in the clinical application of duramater replacement in neurosurgery cases. This study aimed to characterize the histological properties of dry-lyophilized amniotic membrane, fresh amniotic membrane (AM), and duramater membrane in search for a biologicallyderived material suitable for meninges surface reconstruction. This descriptive study was conducted at the Unit3 Laboratory of Animal Test of PT Bio Farma (Persero), Bandung and Cell Biology Laboratory of the Faculty of Medicine Universitas Padjadjaran Bandung. Fresh Macaca fascicularis placenta from healthy donors,classified as specific pathogen-free for TB, SIV, SV40, Polio type 1,2,3, Foamy virus and Herpes B virus, were obtained from selected caesarean sections. The harvested dried and fresh AM and duramater membrane were stained with hematoxylin-eosin and prepared for characterization. Histological examination of dry-lyophilized and fresh AM showed similar results. Histologically, AM is represented by a single layer of metabolically-active cuboidal to columnar epithelium with microvilli firmly attached to a basement membrane and an avascular and relatively sparsely populated stroma. Meninges layers consists of 3 layers: duramater, arachnoid membrane, and piamater. Most of these cells have the same characteristics as fibroblasts, including long organelles and nuclei with various levels of fibril formation. The histological study of amniotic membrane and duramater membrane shows comparable results. The AM is a biologically-derived material suitable for meninges surface reconstruction since its histological structure is somewhat similar to that of the duramater. Its structure is ideal for replacing duramater since it has several characteristics, such as having hygroscopic properties, good biocompatibility, relatively easy to apply, and inexpensive.
\end{abstract}

Key words: Dried and fresh amnion membranes, duramater membranes, non-human primate

\section{Karakteristik Histologis Membran Amnion Jenis Kering dan Segar dengan Membran Duramater pada Primata Non-Human Macaca fascicularis}

\begin{abstract}
Abstrak
Membran Amnion (AM), merupakan limbah rumah sakit, merupakan sumber yang potensial utk donor jaringan. Ada beberapa jenis AM, diantaranya dried dan fresh AM. AM diproyeksikan untuk dapat dipergunakan secara klinis sebagai pengganti duramater pada beberapa kasus bedah saraf. Penelitian ini untuk mengetahui karakteristik histologis membran amnion kering yang diliofilisasi, membran amnion segar, dan duramater dalam rangka mencari bahan biologis yang cocok untuk rekonstruksi permukaan meninges. Penelitian deskriptif dilakukan di Laboratorium Hewan Uji PT Bio Farma dan Laboratorium Biologi Sel Fakultas Kedokteran Universitas Padjadjaran. Plasenta Primata non-human Macaca fascicularis segar dari donor sehat yang bebas dari patogen spesifik TB, SIV, SV40, Polio tipe 1, 2, 3, virus Foamy dan virus Herpes B, diperoleh dari seksio sesarea. Lalu, dilakukan pewarnaan dengan hematoxylin-eosin untuk membran amnion kering dan segar, serta membran duramater untuk mengetahui karakterisasi histologisnya. Pemeriksaan histologis membran amnion kering-yang aktif bermetabolisme hingga kolumnar dengan mikrovili; melekat kuat pada membran basal dan stroma yang avaskular dan relatif jarang. Lapisan meninges terdiri dari 3 lapisan: duramater, arachnoid, dan piamater. Sebagian besar sel-sel ini memiliki karakteristik yang sama dengan fibroblas. Membran amnion adalah material yang secara biologis cocok untuk rekonstruksi permukaan meninges, karena struktur histologinya agak mirip dengan duramater. Oleh karena itu, secara struktur membran amnion ideal untuk menggantikan duramater karena memiliki beberapa karakteristik seperti sifat higroskopis, biokompatibilitas baik, mudah diterapkan, dan murah.
\end{abstract}

Kata kunci: Membran amnion segar dan kering, membran duramater, primata non-human

Corresponding Author: Ahmad Faried, Department of Neurosurgery Faculty of Medicine Universitas Padjadjaran/Dr. Hasan Sadikin General Hospital Bandung, Jalan Pasteur No. 38 Bandung, West Java, Indonesia, Email: ahmad.faried@unpad.ac.id 


\section{Introduction}

Being a hospital waste product, amniotic membrane (AM) is an effective source of allograph tissue. There are several types of AM, namely dried (lyophilization) and fresh-AM., ${ }^{1,2}$ Fresh AM require a short time interval between the harvesting of the tissue and the implementation of the transplant, while freeze-dried AM allows for more flexibility in their use. ${ }^{3}$ Fresh AM has a regenerative effect that is greater than preserved AM due todecreased number of active cells which can reduce growth factors. ${ }^{4}$ Lyophilization is a preservation method by removing water from the tissue by sublimation, causing inhibition of damaging chemical reactions and changes in the tissue. ${ }^{2,5}$, Amniotic membrane is a bio-resource with special characteristics that can be used as a graft to repair damage to the duramater. AMs consists of two types of cells: epithelial cells, or known as epithelial amnion stem cells, on the amnion surface and amnion mesenchymal stem cells that are scattered in the stroma. ${ }^{7}$ Epithelial of amnion stem cells are non-tumorigenic when transplanted in immunodeficient experimental animals. It is also genetically stable and is proven to be safe in the clinical use on several conditions. ${ }^{1,8}$ The amniotic mesenchymal stem cells have the characteristics of low immunogenicity, anti-inflammatory function, and non-tumorigenic. ${ }^{1,7}$

The success of AM in the application of duramater replacement surgery (duraplasty) depends on its ability to differentiate according to the conditions of the dural micro-environment. The multipotent characteristic of AM in duraplasty will be determined by the strength, speed, accuracy of AM cell differentiation, adhesion, and fusion into the duramater tissue. These characteristics are related to the laminin, one of the proteins found in AM basement membrane. Laminin plays an important role in cell differentiation, formation, and migration, as well as tissue regeneration. ${ }^{9,10}$ To understand the success rate of duraplasty procedures using amniotic membranes, a preliminary histological analysis on the characterization of each AM membrane was performed.

\section{Methods}

This study was approved by the Ethics Committee of the Institutional of Animal Care and Use Ethics Commission (IACUC) of PT Bio Farma (Persero) through the issuance of the ethical clearance No. 01/IACUC-BF/III/2017 with a validity period of 2 years from April 14, 2017 to 2019.This was a descriptive study conducted at Unit-3 Laboratory of Animal Test PT. Bio Farma (Persero), Bandung and Biology Cell Laboratory of the Faculty of Medicine Universitas Padjadjaran, Jatinangor. This study was conducted from 2018 to 2019.

Fresh Macaca fascicularis placenta (Fig. $1 \mathrm{~A}, \mathrm{~B}$ ) from healthy donors (female, age 3-4 years old, \pm 3000 grams and free from specific pathogens such as TB, SIV, SV40, Polio type 1, 2 , and 3, Foamy virus, and Herpes B virus were obtained from selected caesarean sections at Unit-3 Laboratory of Animal Test PT Bio Farma (Persero), Bandung. The AMs were then carefully separated from the chorion (Fig. 1C), which was then discarded. Then,after an immediate wash of three to five times with $0.9 \% \mathrm{NaCl}$ solution to remove blood and mucus, fresh AMs were successfully prepared.

Subsequently, the AM was soaked in $0.05 \%$ sodium hypochlorite solution for 10 minutes $(\mathrm{pH}$ solution was neutral) and then placed in a water bath shaker filled with sterile $\mathrm{NaCl} 0.9 \%$ solution and kept in room temperature.The solution was regularly changed every $15 \mathrm{~min}$ for two and a half hours. Next, the AM was washed, stretched, and placed on a sterile gauze pad (Fig. 2A) with the chorion side facing the screen before being cut into the desired size. This procedure was performed in a laminar airflow cabinet. The membrane was then placed on a sterile tray and stored in a deep freezer for 24 hours as a part of the freeze-drying process and was stored in the freezer for 6 hours until the water content of AM has reach approximately 6-7\%. After that, AM was sterilized using ethylene oxide.

Fresh Macaca fascicularis duramater from healthy donors (male, age 3-4 years old, 3000 gram of body weight, free frp, specific pathogens such as TB, SIV, SV40, Polio type 1, 2, and 3, Foamy virus and Herpes B virus) were obtained from selected craniotomy at Unit-3 Laboratory of Animal Test PT. Bio Farma, Bandung. The duramaters were then carefully washed $3-5 \mathrm{x}$ with $0.9 \% \mathrm{NaCl}$ solution to remove the remaining blood. All dried and fresh AM and duramater membranes specimens were fixed in formaldehyde, cut perpendicularly to the surface, then embedded in paraffin and sectioned at 4 micron of thickness. Staining was done with hematoxylin eosin (HE) for each type of tissue examined, dry-lyophilized AM, fresh AM, and also duramater membrane. 

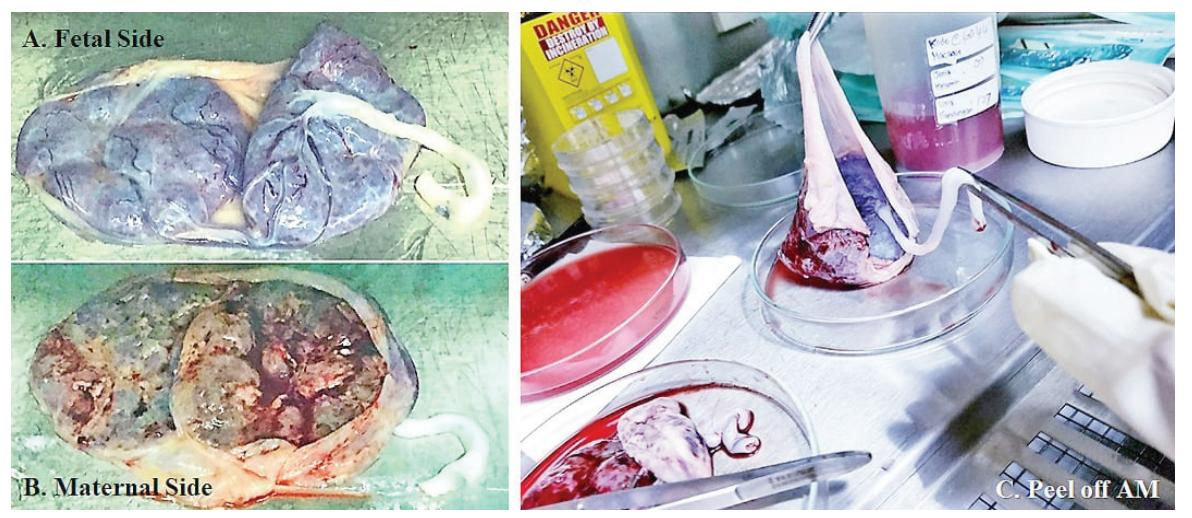

Figure 1 Photograph of a Macacafascicularis Placenta After Cesarean Section; it was Taken at Both the Fetal and Maternal Side (A). The AM Carefully Separated from the Chorion (B)

\section{Results}

The histological appearance of the driedlyophilized AM provides a picture of the epithelium that maintains its organization as a single layer of cuboidal cells but with more vacuolar degeneration. Some areas appears to be layered with loss of cells and edematous stroma (Fig. 2B). Gupta has shown the presence of collagen (types I, III, IV, and V) and fibronectin. ${ }^{11}$ In contrast, collagen VII, and laminin-5 were expressed on the basement membrane side of dried-AM.

The fresh AM (Fig. 2C) consists of an epithelial monolayer, a thick basement membrane, and an avascular stroma (Fig. 2D). The AM contains no blood vessels or nerves; instead, the nutrients are supplied directly by diffusion of the amniotic fluid and/or from the underlining decidua. The innermost layer, the layer closest to the fetus, is the amniotic epithelium and consists of a single layer of cells uniformly arranged on the basement membrane. The compact layer of stromal matrix adjacent to the basement membrane forms the main fibrous skeleton of the AM. The collagens of the compact layer are secreted by mesenchymal cells situated in the fibroblast layer. Interstitial collagens (types I and III) predominate this layer and form parallel bundles that maintain the mechanical integrity of AM. Collagens type
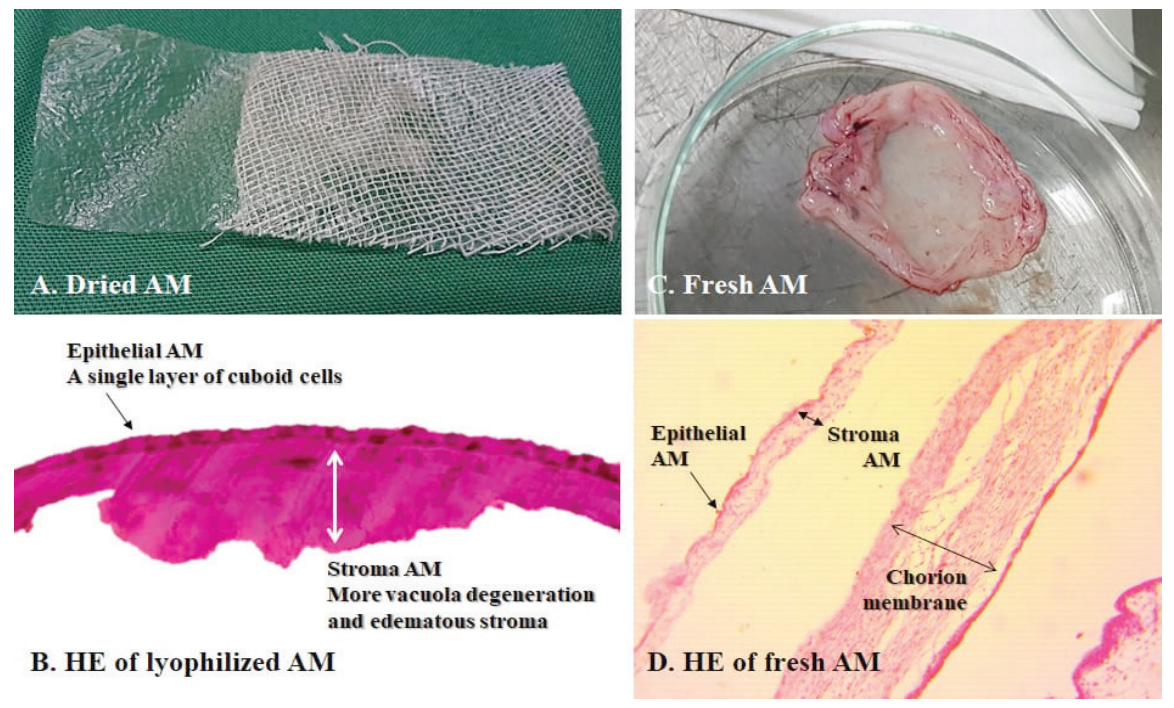

Figure 2 Macrographic (A) and Histologic (B) Apperance of the Dried-AM (Hematoxylin and Eosin 400x) Macrographic (C) and Histologic (D) Apperance of the Fresh-AM (Hematoxylin and Eosin 400x) 

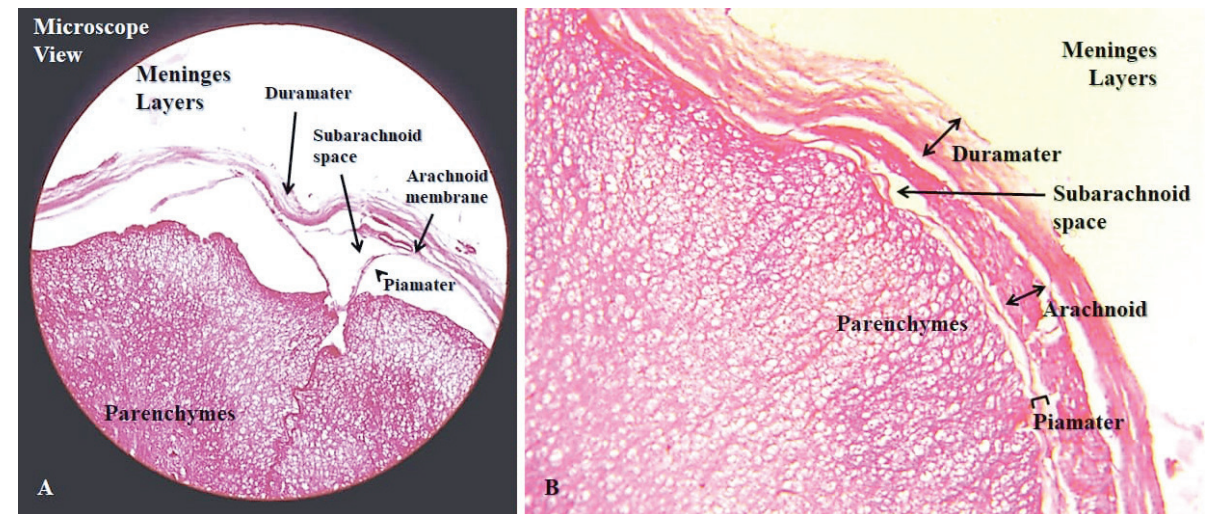

Figure 3 Histologic from Microscopic View (A) and Magnification 400x (B) Apperance of the Meninges Layers (Hematoxylin and Eosin)

$\mathrm{V}$ and VI form filamentous connections between interstitial collagens and the epithelial basement membrane. The intermediate layer (spongy layer or zona spongiosa) of the stromal matrix sits adjacent to the chorionic membrane.

The meninges has three layers: duramater, arachnoid membrane, and piamater (Fig. $3 \mathrm{~A}$ ). Duramater is called pachymeninx (thick meninges) whereas arachnoid membrane and piamater are referred to as leptomeninx (thin meninges) (Fig. 3B). Most of these cells have the same characteristics as fibroblasts, including long organelles and nuclei with various levels of fibrile formation. However, there are few flat cells with more organelles and the nucleus is oval in shape without a tendency to form fibrils. These cells are located between the extracellular collagen fibers that intersect with each other, mixed with a number of micro-fibrils and elastic fibers that are seen in a much lower number. This extracellular material is responsible for the strength of the periosteal layer. Some osteocytes, nerve fibers, and blood vessels are also found in the periosteal layer.

\section{Discussion}

In this study, the AM used was taken from from NHP, Macaca fascicularis (MF). The MF placenta and human placenta are similarbut the MF placenta has longer cell column anchoring villi when compared to humans. ${ }^{12}$ The duration of pregnancy in MF is 160 days compared to 280 days in humans. ${ }^{13} \mathrm{AM}$ is made of an extra-embryonic tissue and consists of a fetal side (amnion) and a maternal side (chorion). The amnio-chorionic membrane outlines the external borders of the sac which encloses the fetus, whereas the innermost layer of the sac is AM. ${ }^{11}$

Histologically, AM is represented by a single layer of metabolically very active cuboidal to columnar epithelium with microvilli that is firmly attached to a basement membrane and an avascular and relatively sparsely populated stroma. ${ }^{14,15}$ The basement membrane is composed of type IV, V and VII collagens (also found in duramater membranes) in addition to fibronectin and laminin..$^{11,15}$ The stroma is further divided into three contiguous but distinct layers, i.e. the inner compact layer which is in contact with the basement membrane and contributes to the tensile strength of the membrane; the middle fibroblast layer, which is thick and made up of a loose fibroblast network; and the outermost spongy layer. ${ }^{15}$ There are no nerves, muscles, or lymphatic vessels in AM. A comparison between dry and fresh AM was carried out in this study. Fresh AM has a short time interval between the procurement of the tissue and the implementation of the transplant while dried amniotic membranes can allow more flexibility in their use. ${ }^{16}$ Fresh AM has a regenerative effect that is greater than that of dried amniotic membranes due to decreased active cells which can reduce growth factors. ${ }^{4,17}$

The dried AM used in this study was lyophilized AM tissue. This is a method of preservation done by removing water from the tissue through sublimation that inhibits adverse chemical reactions and tissue changes. The lyophilized tissue is then able to be stored at room temperature for long periods of time and allows easy transportation., ${ }^{4,6}$ Previous studies found that lyophilized amniotic 
membranes decrease protein expressions. This is due to the denaturation of the protein during the lyophilization process. Protein damage occurs due to the drying process. This protein denaturation produces changes in its structure. Changes in the structure of this protein can also affect the protein's function. ${ }^{6}$

Histological appearance of the lyophilized AM provides a picture of the epithelium that retains its organization as a cuboidal cell layer but with more vacuolar degeneration and some areas appear to be layered and lose cells and stroma looks edematous. Immunohistochemistry shows the presence of collagen IV to form a continuous flat line along the base membrane but appears thinner in the lyophilized amniotic membrane. ${ }^{6}$ Using microscopic electron scanning, duramater can further be divided into 5 different layers as follows: the layer facing the inside of the skull (the surface layer of bone) ( $\alpha$ ), the outer median layer $(\beta)$, the vascular layer $(\gamma)$, the layer internal medial $(\delta)$, and the layer facing the arachnoid $(\varepsilon)$ membrane..$^{18}$ The expression of the extracellular matrix component in duramater is found to be strong, containing collagen type I and III; however, collagen type II is not found in the duramater. The expression of collagen IV is different from collagen I and III fibers in the collagen IV membrane, especially in the perivascular basement membrane. The expression of fibronectin in the duramater is very strong. ${ }^{19}$

In conclusions, the histologic appearance between amniotic membrane and duramater membrane is found to be comparable. The histological examination of the amniotic membrane sample resembles duramater tissue with enriched dense fibers and several cellular components, which is similar to physiological duramater. ${ }^{20}$ The AM collagen has the ability to fuse with the existing duramater and will trigger a successful regeneration with minimal foreign body reactions. Hence, AM is a biologicallyderived material suitable for meninges surface reconstruction since its histological structure is somewhat similar to that of the duramater. There are various indications of the use of amniotic membrane in neurosurgery, ranging from neurotrauma to the reconstruction of meninges layer defect caused by brain tumor. Its structure is ideal for replacing duramater since it has several characteristics, such as hygroscopic, good biocompatibility, easy application, and inexpensive. Last but not least, the very good cosmetic results and LCS leakage improvement are also worth mentioning.

\section{References}

1. Miki T. Amnion-derived stem cells : in quest of clinical applications. Stem Cell Res Ther. 2011;2(3):1-11.

2. Jones GLA. Amniotic membrane in ophthalmology: properties, preparation, storage and indications for grafting-a review. Cell Tissue Bank. 2017;18(2):193-204.

3. Chopra A, Thomas BS. Amniotic membrane: a novel material for regeneration and repair. J BiomimBiomater Tissue Eng. 2013;18:106.

4. Ihsan P. The difference of epidermal growth factor concentration between fresh and freeze-dried amniotic membranes. J Oftalmol Indones. 2009;7(2):62-6.

5. Lei J, Priddy LB, Lim JJ, Massee M, Koob TJ. Identification of extracellular matrix components and biological factors in micronized dehydrated human amnion/ chorion membrane. Wound Heal Soc. 2017;6(2):43-53.

6. Rodríguez-Ares MT, López-Valladares MJ, Touriño R, Vieites B, Gude F, Silva MT, et al. Effects of lyophilization on human amniotic membrane. Acta Ophthalmol. 2009;87:396403.

7. Vidane AS, Souza AF, Sampaio RV, Bressan FF, Pieri NC, Martins DS, et al. Cat amniotic membrane multipotent cells are nontumorigenic and are safe for use in cell transplantation. Stem Cells Cloning. 2014;7:71-8.

8. Mamede AC, Carvalho MJ, Abrantes AM, Laranjo M, Maia CJ, Botelho MF, et al. Amniotic membrane: from structure and functions to clinical applications. Cell Tissue Res. Cell Tissue Res. 2012;349(2):447-58.

9. Roubelakis MG, Trohatou O, Anagnou NP. Amniotic fluid and amniotic membrane stem cells : marker discovery. Stem Cell Int. 2012;2012:1-9.

10. Hamill KJ, Kligys K, Hopkinson SB, Jones JCR. Laminin deposition in the extracellular matrix: a complex picture emerges. J Cell Sci. 2009;122(24):4409-17.

11. Gupta A, Kedige SD, Jain K. Amnion and chorion membranes: potential stem cell reservoir with wide applications in periodontics. Int J Biomater. 2015;2015:1-7.

12. Enders AC, Blankenship TN. Comparative placental structure. Adv Drug Deliv Rev. 1999;38(1):3-15

13. Disposition D. The macaque placenta-a minireview. Soc Toxicol Pathol. 2008;36:108-18.

14. Niknejad H, Peirovi H, Jorjani M, Ahmadiani 
A, Ghanavi J, Seifalian AM. Properties of the amniotic membrane for potential use in tissue engineering. Eur Cell Mater. 2008;15:88-99.

15. Malhotra C, Jain AK. Human amniotic membrane transplantation: different modalities of its use in ophthalmology. World J Transplant. 2014;4(2):111-121.

16. Jirsova K, Jones GLA. Amniotic membrane in ophthalmology: properties, preparation, storage and indications for grafting-a review. Cell Tissue Bank. 2017;18(2):193204.

17. Khalil NM, Melek NLF. Histologic and histomorphometric evaluation of lyophilized amniotic membrane in bone healing: an experimental study in rabbit's femur. Futur
Dent J. 2018;4(2):1-6.

18. Adeeb N, Mortazavi MM, Tubbs RS, Cohengadol AA. The cranial dura mater: a review of its history, embryology , and anatomy. Childs Nerv Syst. 2012;28(6):827-37.

19. Knappe UJ, Fink T, Fisseler-eckhoff A, Schoenmayr R. Expression of extracellular matrix-proteins in perisellar connective tissue and dura mater. Acta Neurochir. 2010;152(2):345-53.

20. Esposito F, Cappabianca P, Fusco M, Cavallo LM, Bani GG, Biroli F, et al. Collagen-only biomatrix as a novel dural substitute Examination of the efficacy, safety and outcome: clinical experience on a series of 208 patients. Clin Neurol Neurosurg. 2008;110(4):343-51. 